\title{
ETV6/NTRK3 Fusion Protein
}

National Cancer Institute

\section{Source}

National Cancer Institute. ETV6/NTRK3 Fusion Protein. NCI Thesaurus. Code C99414.

A fusion protein encoded by the ETV6/NTRK3 fusion gene. This protein is comprised of the $\mathrm{N}$-terminal half of the transcription factor ETV6 protein, including the pointed domain, followed by most of the C-terminal cytoplasmic domain of the NT-3 growth factor receptor protein, including the protein tyrosine kinase domain. 